\title{
PENINGKATKAN HASIL BELAJAR PENGHEMATAN AIR MELALUI METODE PEMBELAJARAN STRUKTURAL SISWA KELAS V SD
}

\author{
Sunarti
}

\author{
SDN 3 Depok Kec. Bendungan Kab. Trenggalek \\ Email: ssunarti7@gmail.com
}

\begin{tabular}{l}
\hline Tersedia Online di \\
\hline http://www.jurnal.unublitar.ac.id/ \\
index.php/briliant \\
\hline
\end{tabular}

\section{Sejarah Artikel}

Diterima pada 16 Januari 2017

Disetuji pada 22 Januari 2017

Dipublikasikan pada 1 Februari 2017 Hal. 73 - 79

\section{Kata Kunci: \\ hasil belajar, penghematan air, pembelajran structural,}

\begin{abstract}
Abstrak: Penelitian ini menggunakan penelitian tindakan (action research) sebanyak dua putaran. Setian putaran terdiri dari empat tahap yaitu: rancangan, kegiatan dan pengamatan, refleksi, dan refisi. Sasaran penelitian ini adalah Siswa kelas V SD Negeri 3 Depok Kecamatan Bendungan Kabupaten Trenggalek Tahun Pelajaran 2012/2013. Data yang diperoleh berupa hasil tes formatif, lembar observasi kegiatan belajar mengajar.Dari hasil analis didapatkan bahwa prestasi belajar siswa mengalami peningkatan dari siklus I sampai siklus II yaitu masing-masing $64.00 \%$, dan $76.00 \%$. Kesimpulan dari penelitian ini adalah metode pembelajaran struktural dapat berpengaruh positif terhadap motivasi belajar Siswa kelas V SD Negeri 3 Depok Kecamatan Bendungan Kabupaten Trenggalek Tahun Pelajaran 2012/2013.
\end{abstract}

Upaya peningkatan kualitas pendidikan di Indonesia tidak pernah berhenti. Berbagai terobosan baru terus dilakukan oleh pemerintah melalui Depdiknas. Upaya itu antara lain dalam pengelolaan sekolah, peningkatan sumber daya tenaga pendidikan, pengembangan/penulisan materi ajar, erta pengembangan paradigma baru dengan metodologi pengajaran.

Pembelajaran yang dilakukan di sekolah dilaksanakan agar siswa menjadi aktif siswa harus mengerjakan banyak sekali tugas. Mereka harus menggunakan otak, mengkaji gagasan, memecahkan masalah, dan menerapkan apa yang mereka pelajari. Belajar aktif harus gesit, menye-nangkan, bersemangat dan penuh gairah. Siswa bahkan sering meninggalkan tempat duduk mereka, bergerak leluasa dan berfikir keras Untuk bisa mempelajari sesuatu dengan baik, kita perlu mendengar, melihat, mengajukan pertanyaan tentangnya, dan membahasnya dengan orang lain. Bukan Cuma itu, siswa perlu "mengerjakannya", yakni menggambarkan sesuatu dengan cara mereka sendiri, menunjukkan contohnya, mencoba mempraktekkan keterampilan, dan mengerjakan tugas yang menuntut pengetahuan yang telah atau harus mereka dapatkan.

Sementara kondisi yang terjadi di sekolah adalah masih lemahnya guru dalam mengkondisikan siswa agar menjadi aktif sehingga sering muncul kendala kendala dalam pembelajaran tidak hanya target tidak tercapai tetapi cenderung mengarah pada kemampuan siswa dalam memahami materi tertentu lemah. 
Kelemahan pemahaman terhadap materi juga dialami oleh siswa kelas V SD Negeri 3 Depok Kecamatan Bendungan Kabupaten Trenggalek Pada Mata Pelajaran Tahun Pelajaran 2012/2013 terutama materi Memahami pentingnya penghematan energi

Dengan menyadari gejala-gejala atau kenyataan tersebut diatas, maka dalam penelitian ini penulis penulis mengambil judul "Implementasi Metode Pembelajaran Struktural Pada Siswa kelas V SD Negeri 3 Depok Kecamatan BendunganKabupaten Trenggalek Tahun Pelajaran 2012/2013 untuk meningkatkan hasil belajar Memahami pentingnya penghematan energi."

Bertitik tolak dari latar belakang diatas maka penulis merumuskan permasalahannya sebagi berikut: 1) Bagaimanakah peningkatan Memahami pentingnya penghematan energi siswa dengan diterapkannya metode struktural pada siswa Kelas V SD Negeri 3 Depok Kecamatan Bendungan Kabupaten Trenggalek tahun pelajaran 2012/2013?, 2) Bagaimanakah pengaruh metode struktural terhadap motivasi belajar siswa kelas V SD Negeri 3 Depok Kecamatan Bendungan Kabupaten Trenggalek tahun pelajaran 2012/2013 ?

Sesuai dengan permasalahan di atas, penelitian ini bertujuan untuk: 1) Mengetahui peningkatan prestasi belajar materi Memahami pentingnya penghematan energi siswa setelah diterapkannya metode struktural pada siswa Kelas V SD Negeri 3 Depok Kec. Bendungan Kabupaten Trenggalek tahun pelajaran 2012/2013, 2) Mengetahui pengaruh pemahaman Memahami pentingnya penghematan energi siswa setelah diterapkan metode struktural pada siswa kelas V SD Negeri 3 Depok Kecamatan Bendungan KabupatenTrenggalek tahun pelajaran 2012/2013.

Penelitian ini dapat memberikan manfaat bagi: 1) Sekolah, sebagai penentu kebijakan dalam upaya meningkatkan prestasi belajar siswa khususnya pada mata pelajaran sains. 2) Guru, sebagai bahan pertimbangan dalam menentukan metode pembelajaran yang dapat memberikan manfaat bagi siswa. 3) Siswa, dapat meningkatkan motiviasi belajar dan melatih sikap sosial untuk saling peduli terhadap keberhasilan siswa lain dalam mencapai tujuan belajar.

Agar tidak terjadi salah persepsi terhadap judul penelitian ini, maka perlu didefinisikan hal-hal sebagai berikut: 1) Metode struktural adalah: Pembelajaran yang secara sadar dan sistematis mengembangkan interaksi yang silih asah, silih asih, dan silih asuh antar sesama siswa sebagai latihan hidup di dalam masyarakat nyata. (Abdurrahman dan Bintoro, 2000: 78)

Karena keterbatasan waktu, maka diperlukan pembatasan masalah yang meliputi: 1) Penelitian ini hanya dikenakan pada siswa kelas VI SD Negeri 3 Depok Kecamatan Bendungan KabupatenTrenggalek tahun pelajaran 2012/2013. 2) Penelitian ini dilaksanakan pada bulan April semester Genap tahun pelajaran 2012/2013. 3) Materi yang disampaikan adalah Memahami pentingnya penghematan energi.

\section{METODE}

Penelitian ini merupakan penelitian tindakan (action research), karena penelitian dilakukan untuk memecahkan masalah pembelajaran di kelas. Penelitian ini juga termasuk penelitian deskriptif, sebab menggambarkan 
bagaimana suatu teknik pembelajaran diterapkan dan bagaimana hasil yang diinginkan dapat dicapai.

Dalam penelitian ini peneliti tidak bekerjasama dengan siapapun, kehadiran peneliti sebagai guru di kelas sebagai pengajar tetap dan dilakukan seperti biasa, sehingga siswa tidak tahu kalau diteliti. Dengan cara ini diharapkan didapatkan data yang seobjektif mungkin demi kevalidan data yang diperlukan.

\section{Tempat, Waktu, dan Subyek Penelitian}

Tempat penelitian adalah tempat yang digunakan dalam melakukan penelitian untuk memperoleh data yang diinginkan. Penelitian ini bertempat di SD Negeri 3 Depok Kecamatan Bendungan Kabupaten Trenggalek tahun pelajaran 2012/2013. Waktu penelitian adalah waktu berlangsungnya penelitian atau saat penelitian ini dilangsungkan. Penelitian ini dilaksanakan pada bulan April semester Genap tahun pelajaran 2012/2013. 3) Subyek penelitian adalah siswasiswi Kelas V SD Negeri 3 Depok Kecamatan Bendungan Kabupaten Trenggalek tahun pelajaran 2012/2013.

\section{Rancangan Penelitian}

Penelitian ini menggunakan Penelitian Tindakan Kelas (PTK). adalah suatu bentuk kajian yang bersifat reflektif oleh pelaku tindakan yang dilakukan untuk meningkatkan kemantapan rasional dari tindakan mereka dalam melaksanakan tugas, memperdalam pemahaman terhadap tindakan-tindakan yang dilakukan itu, serta memperbaiki kondisi dimana praktek pembelajaran tersebut dilakukan.

Sesuai dengan jenis penelitian yang dipilih, yaitu penelitian tindakan, maka penelitian ini menggunakan model penelitian tindakan dari Kemmis dan Taggart (dalam Sugiarti, 1997: 6), yaitu berbentuk spiral dari sklus yang satu ke siklus yang berikutnya. Setiap siklus meliputi planning (rencana), action (tindakan), observation (pengamatan), dan reflection (refleksi). Langkah pada siklus berikutnya adalah perncanaan yang sudah direvisi, tindakan, pengamatan, dan refleksi. Sebelum masuk pada siklus 1 dilakukan tindakan pendahuluan yang berupa identifikasi permasalahan.

\section{Instrumen Penelitian}

Instrumen yang digunakan dalam penelitian ini terdiri dari: 1) Silabus, 2) Rencana pelaksanaan Pelajaran (RPP), 3) Tes formatif

\section{Metode Pengumpulan Data}

Data-data yang diperlukan dalam penelitian ini diperoleh melalui observasi pengolahan belajar aktif, dan tes formatif dan dokumentasi..

\section{Teknik Analisis Data}

Untuk mengalisis tingkat keberhasilan atau persentase keberhasilan siswa setelah proses belajar mengajar setiap putarannya dilakukan dengan cara memberikan evaluasi berupa soal tes tertulis pada setiap akhir putaran. Analisis 
ini dihitung dengan menggunakan statistic sederhana yaitu:1) Untuk menilai ulangan atau tes formatif

Peneliti melakukan penjum-lahan nilai yang diperoleh siswa, yang selanjutnya dibagi dengan jumlah siswa yang ada di kelas tersebut sehingga diperoleh rata-rata tes formatif dapat dirumuskan: Nilai rata-rata $=$ Jumlah semua nilai siswa/Jumlah siswa.

Untuk ketuntasan belajar, Ada dua kategori ketuntasan belajar yaitu secara perorangan dan secara klasikal. Berdasarkan petunjuk pelaksanaan belajar mengajar yaitu seorang siswa telah tuntas belajar bila telah mencapai skor $70 \%$ atau nilai 70 , dan kelas disebut tuntas belajar bila di kelas tersebut terdapat $70 \%$ yang telah mencapai daya serap lebih dari atau sama dengan $70 \%$.

\section{HASIL}

Data penelitian yang diperoleh berupa hasil uji coba item butir soal, data observasi berupa pengamatan pengelolaan belajar aktif dan pengamatan aktivitas siswa dan guru pada akhir pembelajaran, dan data tes formatif siswa pada setiap siklus. Data lembar observasi diambil dari dua pengamatan yaitu data pengamatan pengelolaan belajar aktif yang digunakan untuk mengetahui pengaruh penerapan model belajar aktif dalam meningkatkan prestasi belajar siswa dan data pengamatan aktivitas siswa dan guru. Data tes formatif untuk mengetahui peningkatan prestasi belajar siswa setelah diterapkan belajar aktif.

\section{Siklus I}

Tahap Perencanaan, Pada tahap ini peneliti mempersiapkan perangkat pembelajaran yang terdiri dari rencana pelajaran 1, soal tes formatif 1 dan alat-alat pengajaran yang mendukung. b) Tahap Kegiatan dan Pelaksanaan Pelaksanaan kegiatan belajar mengajar untuk siklus I dilaksanakan pada tanggal 12 Nopember 2012 di Kelas V dengan jumlah siswa 25 siswa. Dalam hal ini peneliti bertindak sebagai guru. Adapun proses belajar mengajar mengacu pada rencana pelajaran yang telah dipersiapkan. Pengamatan (observasi) dilaksanakan bersamaan dengan pelaksaaan belajar mengajar.

Pada akhir proses belajar mengajar siswa diberi tes formatif I dengan tujuan untuk mengetahui tingkat keberhasilan siswa dalam proses belajar mengajar yang telah dilakukan.

Dari tabel di atas dapat dijelaskan bahwa dengan menerapkan pengajaran Struktural diperoleh nilai rata-rata prestasi belajar siswa adalah 69,60\% dan ketuntasan belajar mencapai $64.00 \%$ atau ada 16 siswa dari 25 siswa sudah tuntas belajar. Hasil tersebut menunjukkan bahwa pada siklus pertama secara klasikal siswa belum tuntas belajar, karena siswa yang memperoleh nilai $\geq 70$ hanya sebesar $64,00 \%$ lebih kecil dari persentase ketuntasan yang dikehendaki yaitu sebesar 70\%. Hal ini disebabkan karena siswa masih canggung dengan diterapkannya pengajaran Struktural.

\section{Siklus II}

Tahap perencanaan, Pada tahap ini peneliti mempersiapkan perangkat pembelajaran yang terdiri dari rencana pelajaran 2, soal tes formatif II dan alat- 
alat pengajaran yang mendukung. b) Tahap kegiatan dan pelaksanaan Pelaksanaan kegiatan belajar mengajar untuk siklus II dilaksanakan pada tanggal 17 Nopember 2012 di Kelas V dengan jumlah siswa 25 siswa. Dalam hal ini peneliti bertindak sebagai guru. Adapun proses belajar mengajar mengacu pada rencana pelajaran dengan memperhatikan revisi pada siklus I, sehingga kesalah atau kekurangan pada siklus I tidak terulanga lagi pada siklus II. Pengamatan (observasi) dilaksanakan bersamaan dengan pelaksanaan belajar mengajar. Pada akhir proses belajar mengajar siswa diberi tes formatif II dengan tujuan untuk mengetahui tingkat keberhasilan siswa dalam proses belajar mengajar yang telah dilakukan. Instrument yang digunakan adalah tes formatif II.

Berdasarkan tabel diatas diperoleh nilai rata-rata tes formatif sebesar 73,00 dan dari 25 siswa yang telah tuntas sebanyak 19 siswa dan 6 siswa belum mencapai ketuntasan belajar. Maka secara klasikal ketuntasan belajar yang telah tercapai sebesar $76.00 \%$ (termasuk kategori tuntas). Hasil pada siklus II ini mengalami peningkatan lebih baik dari siklus I. Adanya peningkatan hasil belajar pada siklus II ini dipengaruhi oleh adanya peningkatan kemampuan siswa dalam memahami pembelajaran Struktural . Disamping itu peningkatan kemampuan guru dalam mengelola pengajaran Struktural semakin mantap. c) Refleksi, Pada tahap ini akan dikaji apa yang telah terlaksana dengan baik maupun yang masih kurang baik dalam proses belajar mengajar dengan penerapan pengajaran Struktural.

Dari data-data yang telah diperoleh dapat duraikan sebagai berikut: 1) Selama proses belajar mengajar guru telah melaksanakan semua pembelajaran dengan baik. Meskipun ada beberapa aspek yang belum sempurna, tetapi persentase pelaksanaannya untuk masing-masing aspek cukup besar. 2) Berdasarkan data hasil pengamatan diketahui bahwa siswa aktif selama proses belajar berlangsung. 3) Kekurangan pada siklus-siklus sebelumnya sudah mengalami perbaikan dan peningkatan sehingga menjadi lebih baik. 4) Hasil belajar siswsa pada siklus II mencapai ketuntasan.

Pada siklus II guru telah menerapkan pengajaran Struktural dengan baik dan dilihat dari aktivitas siswa serta hasil belajar siswa pelaksanaan proses belajar mengajar sudah berjalan dengan baik. Maka tidak diperlukan revisi terlalu banyak, tetapi yang perlu diperhatikan untuk tindakah selanjutnya adalah memaksimalkan dan mempertahankan apa yang telah ada dengan tujuan agar pada pelaksanaan proses belajar mengajar selanjutnya penerapan pengajaran Struktural dapat meningkatkan proses belajar mengajar sehingga tujuan pembelajaran dapat tercapai.

\section{PEMBAHASAN}

\section{Ketuntasan Hasil belajar Siswa}

Melalui hasil peneilitian ini menunjukkan bahwa pengajaran Struktural memiliki dampak positif dalam meningkatkan prestasasi belajar siswa. Hal ini dapat dilihat dari semakin mantapnya pemahaman dan penguasaan siswa terhadap materi yang telah disampaikan guru selama ini (ketuntasan belajar meningkat dari sklus I, dan II) yaitu masing-masing $64.00 \%$, dan $76.00 \%$. Pada siklus II ketuntasan belajar siswa secara klasikal telah tercapai. 


\section{Kemampuan Guru dalam Mengelola Pembelajaran}

Berdasarkan analisis data, diperoleh aktivitas siswa dalam proses cara belajar aktif model struktural dalam setiap siklus mengalami peningkatan. Hal ini berdampak positif terhadap proses mengingat kembali materi pelajaran yang telah diterima selama ini, yaitu dapat ditunjukkan dengan meningkatnya nilai rata-rata siswa pada setiap siklus yang terus mengalami peningkatan.

\section{Aktivitas Guru dan Siswa Dalam Pembelajaran}

Berdasarkan analisis data, diperoleh aktivitas siswa dalam proses pembelajaran Sains pada memahami pentingnya penghematan energi dengan cara belajar aktif model struktural yang paling dominan adalah bekerja dengan menggunakan alat/media, mendengarkan/memperhatikan penjelasan guru, dan diskusi antar siswa/antara siswa dengan guru. Jadi dapat dikatakan bahwa aktivitas isiwa dapat dikategorikan aktif.

Sedangkan untuk aktivitas guru selama pembelajaran telah melaksanakan langkah-langkah belajar aktifdengan baik. Hal ini terlihat dari aktivitas guru yang muncul di antaranya aktivitas membimbing dan mengamati siswa dalam mengerjakan kegiatan, menjelaskan/melatih meng-gunakan alat, memberi umpan balik/evaluasi/tanya jawab dimana prosentase untuk aktivitas di atas cukup besar.

\section{KESIMPULAN}

Dari hasil kegiatan pembelajaran yang telah dilakukan selama dua siklus, dan berdasarkan seluruh pembahasan serta analisis yang telah dilakukan dapat disimpulkan sebagai berikut: 1) Pembelajaran dengan metode struktural memiliki dampak positif dalam meningkatkan prestasi belajar siswa yang ditandai dengan peningkatan ketuntasan belajar siswa dalam setiap siklus, yaitu masing-masing $64.00 \%$, dan $76.00 \%$. 2) Penerapan metode struktural mempunyai pengaruh positif, yaitu dapat meningkatkan motivasi belajar siswa untuk mempelajari kembali materi pelajaran yang telah diterima selama ini yang ditunjukan dengan rata-rata jawaban siswa yang menyatakan bahwa siswa tertarik dan berminat dengan metode structural sehingga mereka menjadi termotivasi untuk belajar. 3) Metode struktural memiliki dampak positif terhadap daya ingat siswa, dimana dengan metode ini siswa dipaksa untuk mengingat kembali materi palajaran yang telah diterima selama ini.

\section{SARAN}

Dari hasil penelitian yang diperoleh dari uraian sebelumnya agar proses belajar mengajar Sains lebih efektif dan lebih memberikan hasil yang optimal bagi siswa, makan disampaikan saran sebagai berikut: 1) Untuk melaksanakan belajar aktif memerlukan persiapan yang cukup matang, sehingga guru harus mempu menentukan atau memilih topik yang benar-benar bisa diterapkan dengan metode struktural dalam proses belajar mengajar sehingga diperoleh hasil yang optimal. 2) Dalam rangka meningkatkan prestasi belajar siswa, guru hendaknya lebih sering melatih siswa dengan berbagai metode pengajaran yang sesuai, walau 
dalam taraf yang sederhana, dimana siswa nantinya dapat menemuan pengetahuan baru, memperoleh konsep dan keterampilan, sehingga siswa berhasil atau mampu memecahkan masalah-masalah yang dihadapinya. 3) Perlu adanya penelitian yang lebih lanjut, karena hasil penelitian ini hanya dilakukan di SD Negeri 3 Depok Kecamatan Bendungan Kabupaten Trenggalek tahun pelajaran 2012/2013.

\section{DAFTAR RUJUKAN}

Arikunto, Suharsimi. 2002. Prosedur Penelitian Suatu Pendekatan Praktek. Jakarta: Rineksa Cipta

Ali, Muhammad. 1996. Guru Dalam Proses Belajar Mengajar. Bandung: Sinar Baru Algesindon.

Dayan, Anto. 1972. Pengantar Metode Statistik Deskriptif, tt. Lembaga Penelitian Pendidikan dan Penerangan Ekonomi.

Hadi, Sutrisno. 198. Metodologi Research, Jilid 1. Yogyakarta: YP. Fak. Psikologi UGM.

Melvin, L. Siberman. 2007. Aktif Learning, 101 Cara Belajar Siswa Aktif. Bandung: Nusamedia dan Nuansa.

Ngalim, Purwanto M. 1990. Psikologi Pendidikan. Bandung: PT. Remaja Rosdakarya.

Nurhadi, dkk.2007. Pembelajaran Kontekstual (Contextual Teaching and Learning/CTL) dan Penerapannya Dalam KBK. Malang: Universitas Negeri Malang (UM Press).

Riduwan. 2007. Belajar Mudah Penelitian untuk Guru-Karyawan dan Peneliti Pemula. Bandung: Alfabeta.

Sukmadinata, Nana Syaodih. 2007. Metode Penelitian Pendidikan. Bandung: PT. Remaja Rosdakarya.

Surakhmad, Winarno. 1990. Metode Pengajaran Nasional. Bandung: Jenmars 